ББК 35.74

\title{
BIODEGRADABLE BLENDS BASED ON POLYHYDROXYBUTYRATE: STRUCTURE AND WATER DIFFUSION
}

\author{
Olkhov Anatoliy Aleksandrovich \\ Candidate of Technical Sciences, Associate Professor, Senior Researcher, \\ $\frac{n}{2} \quad$ Laboratory of Prospective Compositional Materials and Technologies, \\ त) Russian University of Economics named after G.V. Plekhanov \\ zalkhov72@yandex.ru \\ Stremyanny Pass., 36, 117997 Moscow, Russian Federation

\section{Markin Valeriy Sergeevich} \\ Candidate of Chemical Sciences, Senior Researcher, \\ Laboratory of Diffusion Phenomena in Polymer Systems, \\ N. N. Semenov Institute of Chemical Physics, RAS \\ aolkhov72@yandex.ru \\ Kosygina St., 4, 119991 Moscow, Russian Federation

\section{Kosenko Regina Yudelevna} \\ Candidate of Chemical Sciences, Senior Researcher, \\ Laboratory of Diffusion Phenomena in Polymer Systems, \\ N. N. Semenov Institute of Chemical Physics, RAS \\ aolkhov72@yandex.ru \\ Kosygina St., 4, 119991 Moscow, Russian Federation

\section{Goldshtrakh Marianna Aleksandrovna} \\ Candidate of Chemical Sciences, Researcher, \\ Laboratory of Diffusion Phenomena in Polymer Systems, \\ N. N. Semenov Institute of Chemical Physics, RAS \\ aolkhov72@yandex.ru \\ Kosygina St., 4, 119991 Moscow, Russian Federation

\section{Zaikov Gennadiy Efremovich} \\ Doctor of Chemical Sciences, Professor, \\ Head of Department of Biological and Chemical Physics of Polymers, \\ Institute of Biochemical Physics named after N.M. Emanuel, RAS \\ chembio@sky.chph.ras.ru \\ Kosygina St., 4, 119334 Moscow, Russian Federation
}




\title{
Iordanskiy Aleksey Leonidovich
}

\author{
Doctor of Chemical Sciences, Professor, \\ Head of Laboratory of Diffusion Phenomena in Polymer Systems, \\ N. N. Semenov Institute of Chemical Physics, RAS \\ aolkhov72@yandex.ru \\ Kosygina St., 4, 119991 Moscow, Russian Federation
}

\section{Pankova Yuliya Nikolaevna}

Candidate of Chemical Sciences, Researcher,

Laboratory of Diffusion Phenomena in Polymer Systems,

N. N. Semenov Institute of Chemical Physics, RAS

aolkhov72@yandex.ru

Kosygina St., 4, 119991 Moscow, Russian Federation

\begin{abstract}
The present article focuses on the study of novel blends based on poly(3hydroxybutyrate) (PHB) and polymers with different hydrophilicity (PELD, PA and PVA). Polymer blends were produced from five ratios of PHB/PELD in an effort to regulate the resistance to hydrolysis or (bio)degradation through the control of water permeability. The relation between the water transport and morphology (TEM data) shows the impact of polymer component ratio on the regulation of water flux in hydrophobic matrix. To elucidate the role of hydrophilicity of second component presenting in the PHB blends, we studied the PHB/PA blends where PA is the polyamide resin composed of statistical copolymer of hexamethyleneadipinate and $\varepsilon$-caprolactam in ratio $1: 1$. The complex of techniques including DCS and FTIR-imaging (for T-scale) demonstrates the interaction between PHB and PA in the temperature ranges of crystallization and melting. The general approach based on FloryHuggins equation is presented as the way to choose the pairs of compatible or partly compatible polymers. Mechanical characteristics and water permeability of films on the basis of PVAPHB mixtures depending on their composition were investigated. It was shown that the additive of PHB increments water permeability of a polymeric matrix, but at major dosage of PHB the permeability of films can be reduced because of ability of PHB to fix water. It was determined by DSC, polarization IR-spectroscopy, WAXS and SAXS-experiments that there is a connection between structural architecture of films at crystalline (or at molecular) level with water permeability and mechanical performances. It was shown that the decreasing of strength of films occurs at PHB concentration more than $20 \%$ (for PVA-PHB mixtures). Blending PHB with PA and PVA could be a simple and effective method to design new matrices for drug delivery in medicine, while the same procedure applied for PHB-PELD system with better resistance to hydrolysis and lower price than initial PHB could be used as novel bioerodible packaging materials.
\end{abstract}

Key words: biodegradable polymer blends, polyhydroxybutyrate, polyamide, polyvinyl alcohol, polyethylene, structure, water diffusion.

\section{Introduction}

The blending of semicrystalline biodegradable and friendly environmental thermoplastics such as bacterial poly(3-hydroxybutyrate) [PHB] with one of the cheapest packing or industrial polymer such as low-density polyethylene [PELD] and with hydrophilic polyamide [PA], polyvinylalcohole [PVA] is a perspective tool to obtain novel materials with combined characteristics of the original components along with economic advantages for material performance.

The families of biodegradable polymers, namely poly- $\alpha$-hydroxyacides (PLA, PGA, and 


\section{ТЕХНИКО-ТЕХНОЛОГИЧЕСКИЕ ИННОВАЦИИ}

their copolymers, PLGA) as well as poly- $\beta$ hydroxyalkanoates (PHA): poly(3hydroxybutyrate) [PHB] and its copolymers, especially with hydroxyvaleriate [PHBV], have superior performance characteristics sufficient to replace a significant portion of petroleum-based plastics used currently in medicine, packaging and food-service industry $[4 ; 16 ; 25]$. Along with biodegradability, the PHAs and their principal member PHB are biocompatible and friendly environmental $[1 ; 10 ; 31]$. In living organism and soil their macromolecules decompose to form the nontoxic intermediates and final products included in carbohydrate metabolism. Besides, bacterial PHB and its copolymers have also proved to be useful as model materials for investigating the physical properties such as crystallization and diffusion.

However, the mechanical deficiency, a narrow processing window as well as yet the high cost of PHB/PHA restrict its application as the friendly environmental, biomedical material. For solution of the three abovementioned problems, we propose the specific blending of PHB, as a pivotal component, and the set of synthetics (LDPE, PVA and polyamide-66) with a different macromolecule polarity to design the (bio)degradable blends/compositions with improved transport and physical characteristics which are useful for description of biodegradation [5] and drug delivery [7].

A widespread procedure for regulating the drug release rate involves controlled changes in the balance of hydrophilic interactions in the polymer matrix at the molecular level. Therefore, regulation of structural organization at the molecular and supramolecular levels makes it possible to control the rate of drug delivery and hence to improve the therapeutic efficacy of new medicines.

\section{Experimental}

In the current study we used PHB in the powder form which was kindly supplied by Biomer Co Krailing (Germany) Lot 216 with $M w=206 \mathrm{kDa}$, density $1.248 \mathrm{~g} / \mathrm{c}^{3}$. The blend films were produced using a) the low-density polyethylene (LDPE), namely commercial product (RF 15803-020 grade) in the form of granules with $M_{\eta}=2.0 \cdot 10^{5} \mathrm{Da}$; and b) the polyamide resin composed of statistical copolymer of hexamethyleneadipinate and $\varepsilon$-caprolactam in the ratio $1: 1$ with $\mathrm{M}_{\eta}=(1,94 \pm 0,06) \cdot 10^{4} \mathrm{Da}$ and containing $38 \%$ of amide groups at content of terminal groups equals $5,0 \pm 0,1 \cdot 10^{-2} \mathrm{~mol} / \mathrm{kg}$ for $\mathrm{NH}_{2}$ groups and $5,3 \pm 0,1 \cdot 10^{-2} \mathrm{~mol} / \mathrm{kg}$ for $-\mathrm{COOH}$ groups. The blends were prepared by solvent casting from chloroform-ethanol solvent combination (both solvents of medical grade quality) and by melt/solid extrusion with singlescrew extruder. A series of LDPE-PHB blends were prepared at the following component ratios $(w / w): 68: 32,84: 16,92: 8,96: 4$, and $98: 2$.

The study is concerned with PVA $8 / 27$ Russian trade mark. The residual acetate group concentration and $\mathrm{Na}$ acetate salt concentration in PVA comprise 8.2 and $0.04 \%$ wt., respectively. Molecular weight of PVA is $64000 \mathrm{~g} / \mathrm{mol}$. with melting point equal to $146{ }^{\circ} \mathrm{C}$. The loaded concentration of PVA:PHB ingredients varied as $100: 0,90: 10,80: 20,70: 30$, $50: 50$, and $0: 100$. The blends were produced using a single screw extruder, ARP-20 with $\mathrm{L} / \mathrm{D}=25$, diameter $=0.20 \mathrm{~cm}$. Electricity heating was used to obtain $180^{\circ} \mathrm{C}$ flat extrusion profile. The components were first premixed in Brabender Plasticorder PCE330 at $170{ }^{\circ} \mathrm{C}$ and at $60 \mathrm{rpm}$ rotor speed after drying the ingredients in an air oven at $101^{\circ} \mathrm{C}$ for $8 \mathrm{~h}$. The screw rotation was $100 \mathrm{rpm}$. The films obtained with final thickness $60 \mathrm{mkm}$ allowed to air cool to room temperature.

FTIR spectra of the blend films recorded with the spectrometer "Bruker IFS-48" (Germany) at resolution $2 \mathrm{~cm}^{-1}$ the number of the scans about 70 . Computer analysis of final spectra performed with the interior programs in the range $500-3500 \mathrm{~cm}^{-1}$. A Perkin-Elmer differential scanning calorimeter (Model DSC7) calibrated with indium was applied for the study of thermal behavior of PHB-PA blends as well as for neat polymers (PHB and PA) separately. Specimens of about $5 \mathrm{mg}$ were encapsulated in aluminium pans and heated/ cooled at the constant rate of $10{ }^{\circ} \mathrm{C} / \mathrm{min}$. The range of heating includes temperature interval from room temperature to $182^{\circ} \mathrm{C}$. The fusion enthalpies $\Delta \mathrm{H}_{\mathrm{PHB}}$ for PHB and $\Delta \mathrm{H}_{\mathrm{PA}}$ for PA were measured to calculate the crystallinity degrees $\alpha_{\mathrm{PHB}}$ and $\alpha_{\mathrm{PA}}$ using the following equations:

$$
\begin{aligned}
& \alpha_{\mathrm{PHB}}=\Delta \mathrm{H}_{\mathrm{PHB}} / \Delta \mathrm{H}_{\mathrm{PHB}}^{\mathrm{o}}\left(1 / w_{\mathrm{PHB}}\right) \cdot 100 \% \quad \mathrm{~A} \\
& \alpha_{\mathrm{PA}}=\Delta \mathrm{H}_{\mathrm{PA}} / \Delta \mathrm{H}_{\mathrm{PA}}^{\mathrm{o}}\left(1 / w_{\mathrm{PHA}}\right) \cdot 100 \%
\end{aligned}
$$


where $w_{i}(i=\mathrm{PHB}$ or $\mathrm{PA})$ is weight fraction of each component in the blend and $\Delta \mathrm{H}^{\mathrm{o}}{ }_{\mathrm{PHB}}$ or $\Delta \mathrm{H}^{\mathrm{o}}{ }_{\mathrm{PA}}$ fully crystalline $\mathrm{PHB}(87 \mathrm{cal} / \mathrm{g})$ or PA (54 cal/g) [9].

Characteristics of the films are studied by wide angle X-ray scattering method (WAXS) at two different directions: parallel and normally to film surface. The tensile modulus and elongation at break of the films were determined from measurements on an "Instron 1122" tensile apparatus. The drawing speed was $1.0 \mathrm{~cm} / \mathrm{min}$ and the results were averaged by at least five tests.

Permeation of water vapor was measured at $23{ }^{\circ} \mathrm{C}$ using the regular two-compartment cell especially designated for PHB films. The relative humidity in feed compartment is maintained constantly at $90 \%$. Water content in registration compartment was very close to zero. Amounts of water transferred through polymer films are determined by weighting of $\mathrm{KOH}$ as water absorber. The deviation of 5 parallel measurements for each experimental point is about $0.85 \%$. The sensing device was accurate to $\pm 0.0001 \mathrm{~g}$ at $23{ }^{\circ} \mathrm{C}$.

\section{Results and Discussion}

\section{General approach in framework of Flory-Huggins theory}

The analysis of water solubilities in accessible intercrystalline area for about 50 polymers with different chemical structures (hydrophilicity) portrays that classification of such polymers can be performed on the basis of combination between the modified Flory-Huggins equation (at $a_{w}=1$ ) and expression for solubility parameter in framework of the regular solution model [29] (eqs. (1) and (2), respectively):

$$
\begin{gathered}
\ln \bigsqcup_{w}+\bigsqcup_{p}+\mathbf{ч}_{w p} \bigsqcup_{p}^{2}=0 \\
\mathbf{\Psi}_{W P}=\frac{\bar{V} w}{R T}\left(Д_{W}^{2}-Д_{P}^{2}\right)
\end{gathered}
$$

Inserting expression for $\mathbf{\Psi}_{W P}$ in eq. (1) we immediately result the following final equation:

$$
\ln \amalg_{w}+\amalg_{p}+\frac{\bar{V} w}{R T}\left(\Delta_{w}^{2}-\Delta_{p}^{2}\right) \amalg_{p}^{2}=0 .
$$

Here the $\varphi_{w}, \varphi_{p}$ are the volume fractions of water and a polymer respectively, and $\delta_{i}$ is the solubility parameters of water and a polymer. $\mathbf{u}_{W P}$ - Flory interaction parameter, $\bar{V}_{w}-$ molar volume of water, $R$ and $T$ are gas constant and absolute temperature $\left({ }^{\circ} \mathrm{K}\right)$, respectively.

The plot of Flory-Huggins equation (at water activity, $\left.a_{w}=1\right)$ in coordinates $\left(\ln \varphi_{w}+\varphi_{p}\right)$ vs. $\left(\mathcal{A}_{w}^{2}-{A_{p}^{2}}_{p}\right){\Perp_{p}^{2}}_{p} \equiv Z$ is generally nonlinear and can be approximated by two intersectional lines in intervals: $Z \leq 600 \mathrm{~J} / \mathrm{cm}^{3}$ for the hydrophilic polymers (PVA, cellulose, chitosan and the like) and $Z \geq 800 \mathrm{~J} / \mathrm{cm}^{3}$ for the hydrophobic polymers (LDPE, HDPE, polypropylene, polystyrene, rubbers and the like), see Fig. 1.

The points located in the vicinity of the intersection point of the above lines, at $600<Z<800 \mathrm{~J} / \mathrm{cm}^{3}$, belong to the moderately hydrophilic polymers [13].

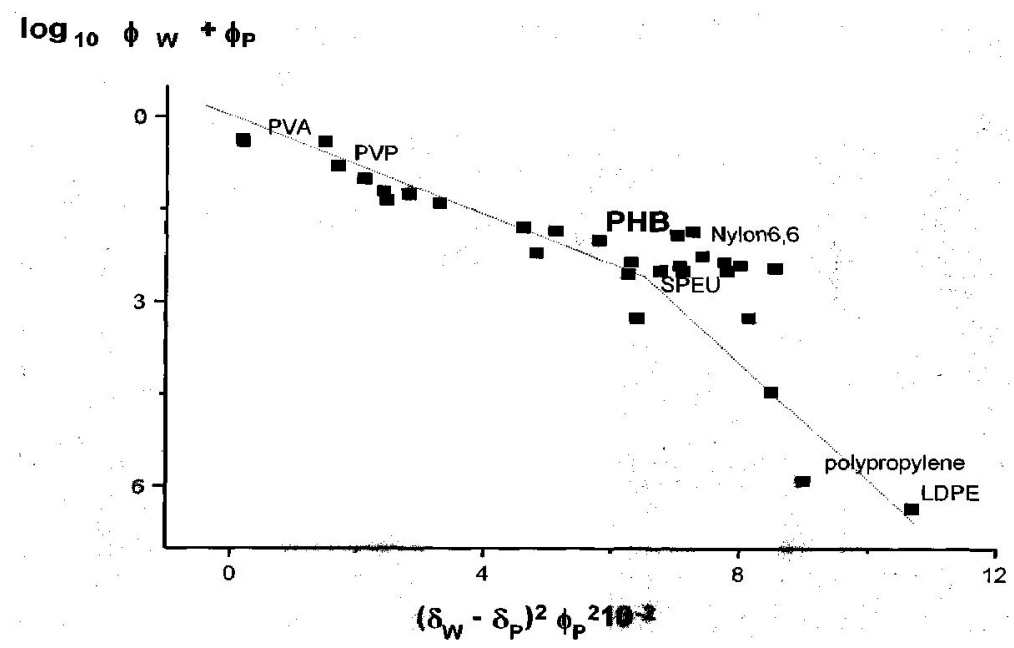

Fig. 1. The pattern of water solubility in polymers with different hydrophilicity [10] in framework of Flory-Huggins equations 
In the Fig. 1 the water equilibrium sorption in the above systems of coordinates is presented. Two polymers (PHB and PHBV) from the family of polyhydroxyalkanoates with Hildebrand solubility parameters $\delta_{p}=19,8$ and $19,4 \mathrm{~J}^{1 / 2} / \mathrm{cm}^{3 / 2}\left(\mathrm{~Pa}^{1 / 2}\right)$ respectively [28] are situated in the vicinity of the intersection point. The obtained data about 55 polymers with different hydrophilicity which have been collected from our work [14]. Variation of second polymer polarity in its blend/composite with the PHB (PHBV) regulates composite morphologies and, hence, both water and drug transport as well as thermophysical and mechanical behavior of polymer systems. Here we initiate our consideration with description of an utmost situation where the PHB has been combined with typical hydrophobic polymer - polyethylene (PELD).

Analyzing the microphotos obtained in our preliminary paper [20] we can distinctly discern the porous space between continuous medium of the major phase of PELD and band-like fibrils of PHB. These materials have microscopically complex structure with random distribution of pore sizes, ranging from a few microns to tens of microns. In packaging or pharmaceutical practice, in order to regulate the water permeability, it is slightly effected by external force arousing during a film preparation or exploitation. Thus, controlling optimal values of the composite parameters such as porosity, permeability and hydrophilicity are important issues in PHB-PE research.

Transport behavior of water in blend of PHB with hydrophobic polymer (PELD)

The total water permeability of the LDPE/ PHB blends $\left(\mathrm{P}_{\mathrm{W}}\right)$ can be described by the following equation:

$$
\begin{gathered}
P_{W}=\alpha_{S}^{\mathrm{PE}} F_{\mathrm{PE}} P_{W}^{\mathrm{PE}}+ \\
+\alpha_{S}^{\mathrm{PHB}} F_{\mathrm{PHB}} P_{W}^{\mathrm{PHB}}+\alpha_{S}^{\text {Int }} P_{W}^{\mathrm{H}}
\end{gathered}
$$

where $P_{W}^{\mathrm{PE}}, P_{W}^{\mathrm{PHB}}$, and $P_{W}^{\mathrm{H}}$ are the water permeabilities in phases of LDPE, PHB, and through the interphase respectively; $\alpha_{S}^{\mathrm{PE}}, \alpha_{S}^{\mathrm{PHB}}$, and $\alpha_{S}{ }^{\text {int }}$ are the fractions of the film cross section possessed by the phase of each component and interphase; $F_{\mathrm{PE}}$ and $F_{\mathrm{PHB}}$ are functions characterizing the effect of polymeric segments' orientation on the water permeability in phases of LDPE and PHB respectively. $\alpha_{S}^{\text {int }}=1-\alpha_{S}^{\mathrm{PE}}-\alpha_{S}{ }^{\mathrm{PHB}}$.

According to the results of scanning electron microscopy [20], the porous structure in the interphase is formed and, hence, parameter $P_{W}^{\text {Int }}$ is equal to the hydraulic permeability [28]. Here the porous medium is modeled as a continuum, composite material and its structure is characterized with a minimal set of properties, namely the porosity $\left(\alpha_{S}{ }^{\text {Int }}\right)$, the hydraulic permeability $\left(P_{W}^{\mathrm{H}}\right)$, which might be functions of position (architecture) and structural element orientation (anisotropy) $F_{\mathrm{PE}}, F_{\mathrm{PHB}}$. Further, $\varphi_{k}$, $\varphi \pi, \varphi v$ are the local volume fractions of cells, hydrated EPS and water in the biofilm. From the local volume balance follows that:

$$
\sigma_{s}^{\mathrm{PE}}+\sigma_{s}^{\mathrm{PHB}}+\sigma_{s}^{\mathrm{int}}=1 .
$$

The final term on the right hand side of eq. (4) reflects the hydraulic movement of water through porous area and usually referred to as Darcy term [6]:

$$
J_{W}^{D a}=-K_{D a} \frac{1}{\sigma_{s} \mathrm{c}_{w}} \frac{d \mathrm{M}}{d x}
$$

where $J_{W}^{D a}$ is the water flow into a pore-containing area $\left(\mathrm{m}^{3}\right.$ [water] $\mathrm{m}^{-2}$ [pore cross-sectional surface area] $\left.\mathrm{s}^{-1}\right)$, $K_{D a}$ is hydraulic Darcy constant $\left(\mathrm{m} \mathrm{s}^{-1}\right)$ and $\mathrm{d} \mu / \mathrm{dx}$ is a water potential gradient $\left(\mathrm{m} \mathrm{s}^{-2}\right)$ expressed through the water activity or the pressure of water vapor.

The expression for water permeabilities through PELD and PHB matrices has a classical form:

$$
J_{W}^{i}=-P_{W}^{i} \frac{d C_{W}}{d x}
$$

where $i$ - index used for PHB or PELD, and $\frac{d C_{W}}{d x}$ is gradient of water concentration.

The Fig. 2 shows the total course of water permeability (fluxes) through the blend films as function of PHB content. The sharp permeability jump from the matrices having the anisotropical orientation of the PHB bands in LDPE to matrices where the PHB fibrils formed the isotropic network is illustrated by corresponding photos [18] reflecting the two different types of morphology.

At the relatively low PHB concentrations (4-8 \% wt.), the water flux resistance is maximal and exceeds the resistance of the initial LDPE film (see Fig. 3).

Then, the resistance is decreased with the increase of PHB concentration. It is significant that the same manners have both the IR 


\section{ТЕХНИКО-ТЕХНОЛОГИЧЕСКИЕ ИННОВАЦИИ}

polarization ratio. Note that in this case mechanical tensile strength dependence on the PHB concentration with minimum is situated at the same PHB/PE fraction, about 4-8 \% [18]. It is apparent from the above data that transport behavior of water in the blended films is substantially affected by the orientation of polymer segments $\left(F_{i}\right)$ in LDPE continuum phase and by the defects/pores formed in interphase areas $\left(\alpha_{S}^{\text {Int }}\right.$ $P_{W}^{\text {Int }}$ in eq. (1)) if one suggests that tensile strength was dominantly determined by defects (pores) of the heterogeneous matrix.

Analysis of extreme points for "transport coefficient - blend content" relationships combined with the morphology features (controlled by FTIR, XRD, SEM and AFM) and thermophysical testing (DSC, TGA) enable us to elucidate the impact of crystallinity and second component nature (macromolecular polarity) upon mechanism of both controlled release and (bio)degradation.

Phase transitions in the blend of PHB with moderately hydrophilic polymer (PA)

On the elaboration of binary polymer composition where both components have moderate hydrophilicity (macromolecule polarity) we have selected poly(3-hydroxybutyrate) [PHB] and copolymer of polyamides PA54C characterized in [13] and hereafter designated by PA acronym. The one of important reasons for such selection was the proximity of their melting points $175.7^{\circ} \mathrm{C}(\mathrm{PHB})$ and $168.3^{\circ} \mathrm{C}(\mathrm{PA})$ and, as consequence, the processing of their blends through the melt became much more efficacious. The other reason is the elasticity of PA at low crystallinity and, hence, we would need that addition of PA to PHB could improve viscouselasticity of the neat PHB.

The assay of repeated cycles 'meltingcrystallization' provided by DSC for PHB-PA composition testifies a PHB crystallinity decrease as the result of their blending. The crystallinity degree was calculated through enthalpy melting on measuring endothermic peak areas as shown in Experimental part. Under blending with moderately hydrophilic polymer (PA), the
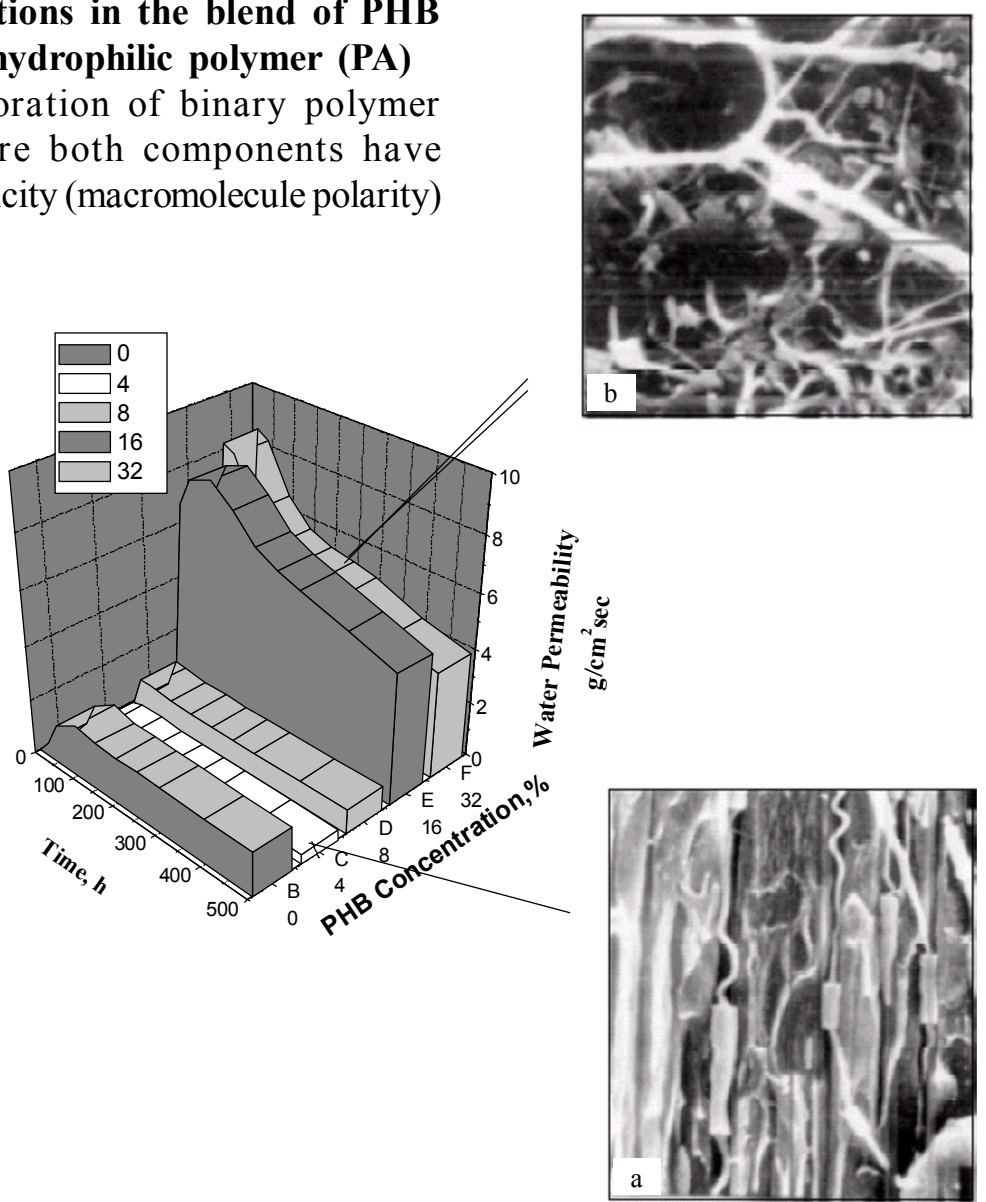

Fig. 2. Water permeability through the blend films prepared on the basis of the different polymer fractions (shown on the top). Simultaneously the photo of anisotropic $(a)$ and isotropic $(b)$ morphologies of the blends. The lines show the correspondence between kinetics and TEM data 
crystallinity decline resembles qualitatively the course of decrease in crystallinity for the system PHB-PVA that is at blending with hydrophilic polymer [20]. It is important that the location of melting point for PHB on DSC curves displaced to low temperature area from the value $175.7{ }^{\circ} \mathrm{C}$ for neat PHB to $168.5^{\circ} \mathrm{C}$ for PHB in the blend at $87.5 \%$ PA.

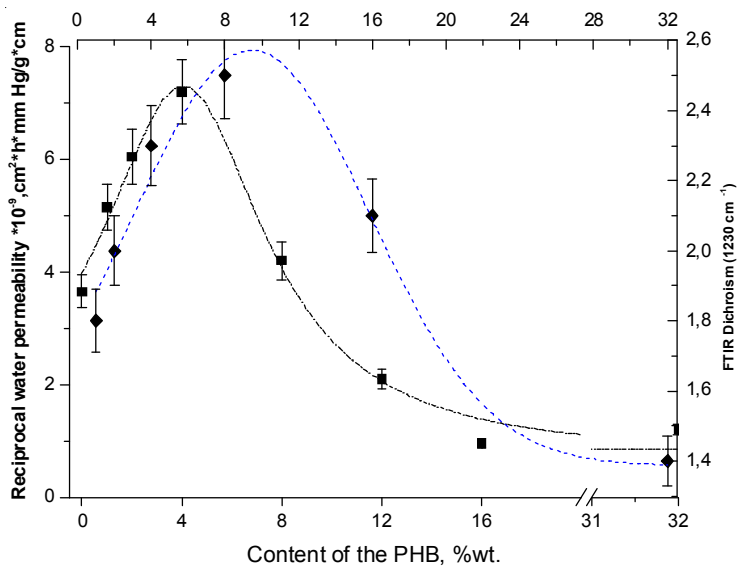

Fig. 3. Comparison of reciprocal permeability of water ( $\bullet$ ), FTIR dichroism ( $\bullet$ ), as functions of PHB content in PHB-LDPE composite films

Recently on the basis of FTIR spectroscopy data [13] we have shown that in the blend films of PHB-PA there is the system of hydrogen bonds which are formed between carbonyl group of PHB and amide one of PA. Taking into account the accessibility of interacting groups in PHB and $\mathrm{PA}$, the maximal interaction estimated as the shift of location for band maximum of carbonyl group happens at mole ratio $\mathrm{PHB} / \mathrm{PA}=1: 1$. With provision for FTIR data we can suggest that in a chilled-down polymer composition the impact of the second component (PA) upon immobilization of PHB kinetic segments causes the decrease in their mobility and, hence, brings the drop of PHB segment fraction involved into crystallization.

The next step of blend crystallinity transfer study embraces the analysis of cooling thermograms from the melts PHB-PA. For all compositions (besides the blend with ratio $\mathrm{PHB} /$ $\mathrm{PA}=1: 9$ ) there are two peaks with appropriate resolution on the temperature scale. Each peak belongs to the successive crystallization of individual components in the blend. It is interesting that the low-temperature maximum reflects the crystallization of the PHB melted at $\sim 175{ }^{\circ} \mathrm{C}$ while the high-temperature peak makes the crystallization of the PA melted at lower temperature about $165^{\circ} \mathrm{C}$. Consequently, the supercooling degree (designated as the difference in melting point and crystallization point) is much higher for the high-crystalline PHB relative to the PA.

For overcooled melts of the PHB blends the addition of second component gradually decreases the temperature of crystallization, as a result of a solid crystalline phase formation in PA. The solidification of PA (its crystalline part) produces steric and kinetic hindrances effecting the PHB crystallization. Along with that, as we said above, the blending PHB and PA decreases the melting point of the former. Generally, the locations of endothermic and exothermic peaks moved on the temperature scale with such manner that the supercooling degree remains nearly constant. In a number of works [20] it has been shown that both the rate of crystallinity and the rate of heterogeneous nucleation increase with the value of supercooling degree $\left(\Delta T_{c m}=T_{m}-\mathrm{T}_{c}\right)$. Therefore, it is quite possible to assume that the formation of crystalline phase in PHB must perform with constant rate and the rate does not depend on the PHB-PA composition.

Enhancing or inhibiting in segmental mobility for the blended components reflecting the melting or crystallization, respectively, can be discovered by the FTIR spectra obtained as the step-like series of temperatures. The Fig. 4 and 5 portray a set of spectra recorded for heated and cooled samples of PHB-PA system.

Here we showed that stretching vibration bands of carbonyl group pertaining ester entity of PHB are very sensitive to "defrosting" in mobility of polymer molecules. Such jump of segment mobility is the result of PHB crystal fusion. A lowfrequency shoulder of multicomposed band of $>\mathrm{C}=\mathrm{O}$ group vibration (at $1724 \mathrm{~cm}^{-1}$ ) disappears in the vicinity of melting temperature of PHB in the PHB/PA $(1: 1)$ blend and for the blend melt above $172{ }^{\circ} \mathrm{C}$ there is the only diffuse band with the maximum at $1740 \mathrm{~cm}^{-1}$. The extended maximum in this area most likely reflects the existence of wide distribution of mobile conformers to be responsible for the vibration of the ester groups in the melt. We emphasize that temperature conforming to mobility deceleration (FTIR data) is in good agreement with melting point (DSC data) for PHB in the blend. 


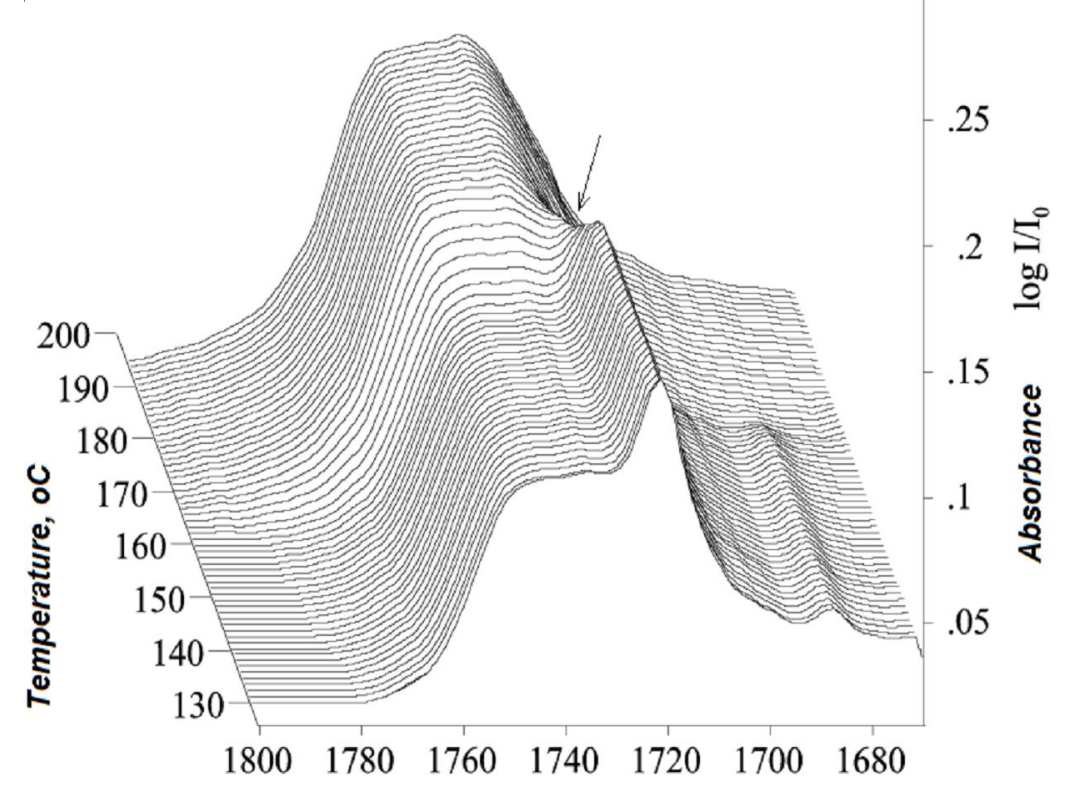

Wavenumbers, $\mathrm{cm}-1$

Fig. 4. FTIR-imaging for melting in the PHB-PA blend in the area of $\mathrm{C}=\mathrm{O}$ group vibration

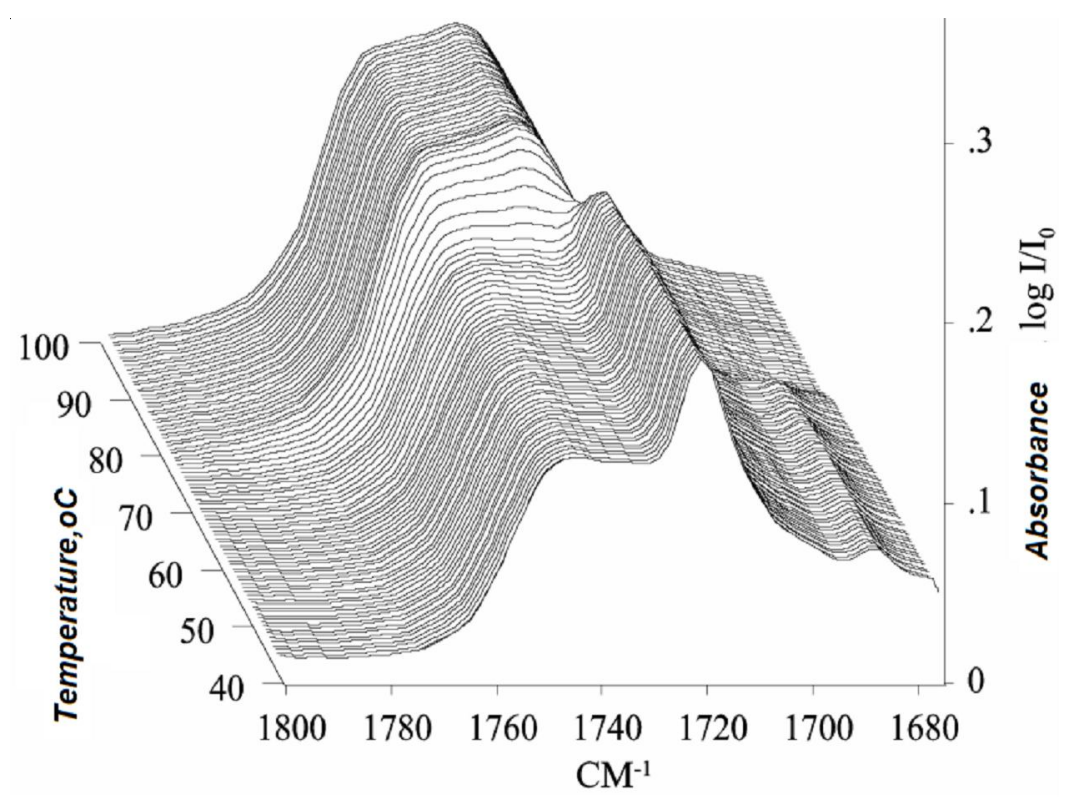

Fig. 5. FTIR-imaging for crystallization in the PHB-PA blend in the area of $\mathrm{C}=\mathrm{O}$ group vibration

The parallel temperature series has been performed under cooling of the melt blend (see Fig. 5). The successive record of the FTIR spectra at different temperatures demonstrate clearly the transfer from the liquid state to crystalline state. In the vicinity of $65^{\circ} \mathrm{C}$ this process is characterized by the sharp appearance of lowfrequency mode mentioned above and related with immobilized carbonyl gropes. Under blend cooling we observe also the coincidence of this temperature with temperature interval of phase transition, measured by DSC procedure.

Summarizing the section devoted to PHB blend with moderately hydrophilic polymer (PA) we have just shown that phase transition is aa thermo-induced process when each polymer component has the proper structure evolution and both components interact each other. The displacements of endothemal peak $\left(T_{m}\right)$ and exothermal peak $\left(T_{c}\right)$ on the temperature scale as 


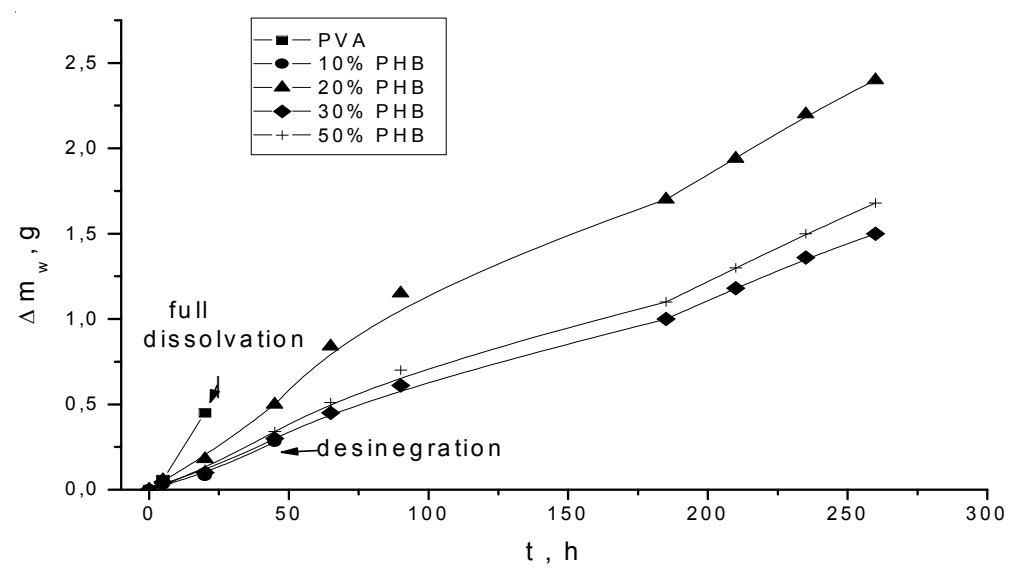

Fig. 6. The quantity of water $(g)$, diffused through PVA/PHB blend films

function of blend composition give also evidences of intermolecular interactions between the polymers forming the novel blend composition. Mechanism of thermophysical behavior can help us to design a novel therapeutic system for controlled drug delivery.

Phase transitions in the blend of PHB with hydrophilic polymer (PVA)

From DSC data the good compatibility of blends for hydrophobic (PHB) and hydrophilic (PVA) polymers is observed until $30 \%$ wt. of PVA. In this concentration interval (0-20\%) the blend permeability monotonically decreased with PHB concentration (see Fig. 6).

In spite of the crystallinity decrease in PVA, the total water diffusion is decreased also due to interaction of hydroxyl groups with carbonyl groups of $\mathrm{PHB}$ and, hence, due to water solubility depression. For both PE/PHB and PVA/PHB blends the specific inflection points are shown. The initial stage of permeability reveals the relaxation of elements of blend structure on the molecular and crystalline levels.

The transformation of the amorphous fields has to effect such important characteristics as permeability and diffusivity of water. The transport processes proceed exclusively in amorphous part of any blend matrix and, hence, this process will be structure-sensitive relative to change of structural organization in intercrystalline fields.

Kinetic curves of vapor water permeation through the blend films at different ration $\mathrm{PHB} / \mathrm{PVA}$ presented in Fig. 6. Contrary to permeability through parent PVA films, all permeability curves through blends have three specific range corresponding to three different ways of water diffusion.
The initial range features the low rate of water permeation where diffusion is conjugated with immobilization of water molecules on functional groups of PHB (ester groups) [16] and more intensively on hydroxyl groups of PVA [12]. In this temporal interval of time the transitional flux of water takes place that is typically for all hydrophilic polymers. The next intermediate range (II) determines the quasi steady-state regime of transport, where water diffusion is complicated by residual structural relaxation more typical for PHB molecules. A rise in vapor water permeation is dictated by both the increase of free volume ratio and segmental mobility in the blends. The last two effects result from screening the functional groups by absorbed water molecules [11] as well as redistribution of hydrogen bonds in the blends as response to water affect [24]. The rupture of hydrogen bonds formed initially between ester (PHB) and hydroxyl (PVA) or between two hydroxyl groups as the effective crosslinks promotes swelling in the blends and as consequence an increase of both water diffusivity and water equilibrium sorption. The third range of permeability curves can be recognized due to the inflection point observed for all samples containing PHB. It seems that to this moment the structural relaxation is completed and the water transport proceeds in accordance with regular diffusion mechanism [23].

The results of DSC scans for PHB-PVA blends and the parent polymers which were prepared by extrusion at various proportion of the components are given in Table.

As was found, the positions of the hightemperature and low-temperature peaks in the 


\section{ТЕХНИКО-ТЕХНОЛОГИЧЕСКИЕ ИННОВАЦИИ}

DSC curves, which correspond to the melting points of the starting components, are almost independent of the blend composition and remain invariable in the whole concentration range under study (see Table). However, the transient region characterizing the glass transition temperature of the PVA-PHB system assumes different positions on the temperature axis depending on the concentration of PHB. This situation is vividly illustrated in Fig. 7, where $T_{g}$ of the blend is seen to increase with the content of PHB.

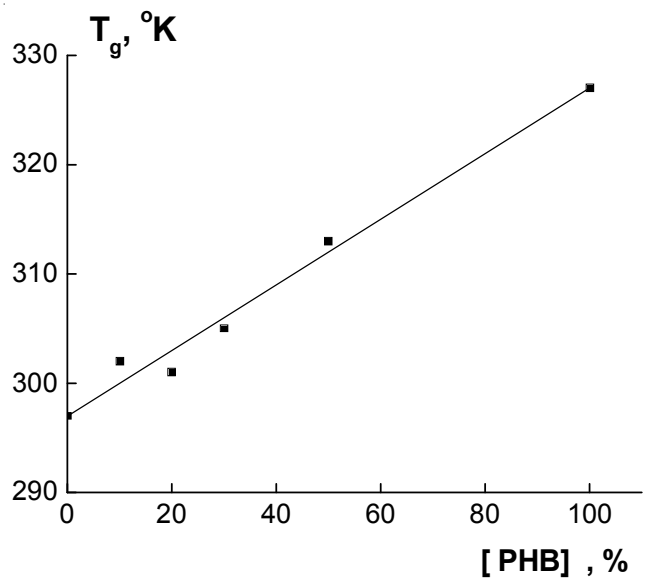

Fig. 7. Dependence glass temperature from concentration of PHB in PVA/PHB blended films

The low-temperature transition between 24 and $54{ }^{\circ} \mathrm{C}$ may be related to the glass transition temperatures $\left(T_{g}\right)$ for both parent polymers (for PHB is $24.1{ }^{\circ} \mathrm{C}$, and PVA is $53.9^{\circ} \mathrm{C}$ ) and polymer segments of these polymers interacting in blends, see [21]. This perceptible shift of $T_{g}$ can reflect the tendency for miscibility of the components. In detail, thermal and physical characteristic analysis will be presented in our forthcoming paper.

Along with thermophysical data and the transparence in PHB-PVA films observed at 0 $30 \%$ concentration interval, the findings of $\mathrm{X}$ -
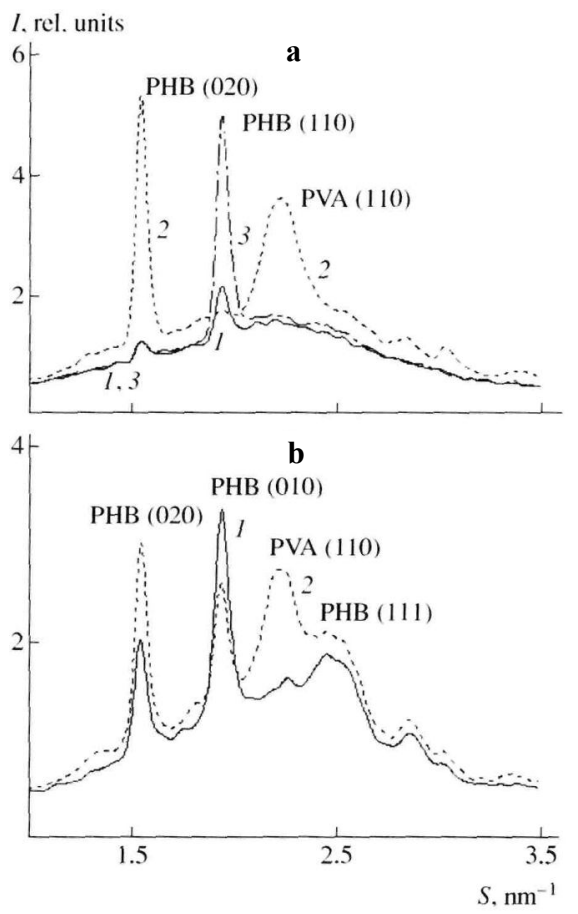

Fig. 8. X-ray diffractograms of the PHB-PVA - films with a composition of $80: 20(a)$ and 70:30 (b) \% wt. recorded alone the orientation axis $(1)$ and at the angle of $90^{\circ}(2)$ or $20^{\circ}(3)$ to the orientation axis.

$S=2 \sin \theta / \lambda$, where $\theta$ is the X-ray scattering angle and $\lambda$ is the wavelength

ray (WAXS) method show that each of the components is capable of forming the own crystalline phase. Analysis of diffractograms (Fig. 8) allows extracting in general spectra the reflexes which pertain to individual crystalline phases of PHB and PVA simultaneously. At all proportion of the components in the blends, PHB conserves the elementary cell parameters $a=0.576 \mathrm{~nm}, b=1,32 \mathrm{~nm}$, and $c=0.596 \mathrm{~nm}$ which correspond to orthorombic elementary cell [22]. The PVA reflexes are typical for quasi crystalline modification (the gamma-form)

\section{Characteristics of the composite films based on PVA and PHB}

\begin{tabular}{|c|c|c|c|}
\hline PVA $:$ PHB, $\%$ & $T_{m}, \mathrm{~K}$ & ${ }^{*} P_{w} \cdot 10^{8},\left[\mathrm{~g} \bullet \mathrm{cm} / \mathrm{cm}^{2} \cdot \bullet \cdot P a\right]$ & ${ }^{* *} C_{w} \cdot 10^{3},\left[\mathrm{~g} / \mathrm{cm}^{3} \cdot \mathrm{Pa}\right]$ \\
\hline $100: 0$ & $402 / 443$ & 2.1 & 0.28 \\
\hline $90: 10$ & $396 / 459$ & 0.56 & 0.068 \\
\hline $80: 20$ & $403 / 443$ & 0.79 & 0.023 \\
\hline $70: 30$ & $405 / 448$ & 0.86 & 0.0075 \\
\hline $50: 50$ & $405 / 451$ & 0.94 & 0.01 \\
\hline $0: 100$ & 449 & 0.0025 & $7.5 \cdot 10^{-4}$ \\
\hline
\end{tabular}

Notes. Two melting temperatures $\left(T_{m}\right)$ of the composite films corresp. 
constructed by parallel-oriented macromolecules in dense packaging [19]. On the diffractogram reflex at $S=2.21 \mathrm{~nm}^{-1}$ corresponds to the own phase of PVA.

WAXS measurements were taken at the different orientation of film position relative to X-ray irradiation beam. For all samples the diffractograms reveal the existence of axial cylindrical texture in PVA. The axis of texture coincides with extrusion direction and, hence, the PVA molecules in quasicrystalline fields oriented along extrusion direction. In samples with 10 and $20 \%$ wt. of PHB a well-defined axial texture of PHB crystallites is evident where the texture axis coincides with direction of extrusion as well. However, the PHB crystallites are oriented relative to the texture axes so that the extrusion direction in line with the axes a of elementary crystalline cell. Hence, the axes of PHB molecules are normally oriented relative to extrusion direction.

Diffractograms of the samples containing 30 and $50 \%$ wt. of PHB show that the most part of crystalline phase in PHB is isotropic, without texture and only residual amount of oriented and textured crystallites is present in $30 \%$ wt. - PHBcontained sample.

These findings allow concluding that in the PHB-PVA blends at $30 \%$ wt. PHB content the structural transition from textured to isotropic crystalline state occurs. Such transition could be attributed to phase inversion of polymer matrix taking place in the same concentration range, about $30 \%$ wt. of PHB. It is commonly known that in the range of phase inversion both crystalline and physical properties of polymer blends are changed, see e.g. [18]. In this work we have studied the effect of structural inversion on mechanical behavior of the blends at different concentrations of PHB. The drastic decrease is observed on the curves tensile strength concentration in the same concentration interval [30]. Besides, on the curve reflecting the dependence of elastic modulus on PHB concentration there is the minimum located in the same concentration interval near $30 \% \mathrm{wt}$. where the phase inversion proceeds. At the low PHB concentrations in the blends, their behavior at rupture is preferably determined by the mechanical properties of PVA while at the PHB concentration more than $30 \%$ wt. these characteristics are closely analogous to the behavior of PHB matrix. The results presented in Fig. 1 and 6 do not contradict the physical concept of phase inversion involving both crystalline fields and intercrystalline (amorphous) fields in the blends.

\section{Conclusion}

We propose a common simplified (relative to e.g. 3D Hansen model [12]) approach for preliminary selection of the pair of polymer components for the production of potentially partly-miscible blends. The approach is based on modified Flory-Huggins equation and used for equilibrium water sorption in polymers with different macromolecule polarity (hydrophilicity). As sample of an immiscible pair forming the blend we studied the PHB/PE composition. The morphological features of $\mathrm{PHB} / \mathrm{PE}$ blend demonstrate the self-reinforced matrix where the minor component (PHB) forms the like-band fibrils embedded in the PELD matrix. Above $16 \%$ of $\mathrm{PHB}$, the blend system undergoes the morphology transfer from oriented PHB structure to isotropic one where the PHB fibrils transform into a network. The distinction between two morphologies reflects the different values of water permeability through the blend films.

To elucidate the role of hydrophilicity of second component presenting in the PHB blends, we studied the PHB/PA blends where PA is the polyamide resin composed of statistical copolymer of hexamethyleneadipinate and $\varepsilon$-caprolactam in ratio $1: 1$. The complex of techniques including DCS and FTIR-imaging (for T-scale) demonstrates the interaction between PHB and PA in the temperature ranges of crystallization and melting. The general approach based on FloryHuggins equation is presented as the way to choose the pairs of compatible or partly compatible polymers. Blending PHB with PA could be a simple and effective method to design new matrices for drug delivery in medicine, while the same procedure applied for PHB-PELD system with better resistance to hydrolysis and lower price than initial PHB could be used as novel bioerodible packaging materials.

In perspective, the heterogeneous LDPE/ PHB, PA/PHB blends and homogeneous PVA/ PHB blends may represent the novel 
biodegradable and biomedical materials. The variation of PHB concentration in the blended films permits to regulate the special morphology and water barrier properties.

\section{REFERENCES}

1. Akiyama M., Tsuge T., Doi Y. Environmental Life Cycle Comparison of Polyhydroxyalkanoates Produced From Renewable Carbon Resources by Bacterial Fermentation. Polymer Degradation and Stability, 2003, vol. 80 (no. 1), pp. 183-194.

2. Baron A.A., Bakhracheva Yu.S. The Method for Lifetime Estimation Through the Mechanical Properties in Tension. Mechanika (Kaunas), 2004, no. 3, pp. 29-32.

3. Baron A.A., Bakhracheva Yu.S., Osipenko A. Fracture Toughness Estimation by Means of Indentation Test. Mechanika, 2007, vol. 67, no. 5, pp. 33-36.

4. Chen G.Q. A Microbial Polyhydroxyalkanoates (PHA)-Based Bio- and Materials Industry. Chem. Soc. Rev., 2009, vol. 38, pp. 2434-2446.

5. Chiellini E., Corti A., D’Antone S., Solaro R. Biodegradation of Poly (Vinyl Alcohol)-Based Materials. Prog. Polym. Sci., 2003, vol. 28, pp. 9631014.

6. Furmaniak S., Terzyk A.P., Gauden P.A., Rychlicki G. Applicability of the Generalised D'Arcy and Watt Model to Description of Water Sorption on Pineapple and Other Foodstuffs. Journal of Food Engineering, 2007, vol. 79, pp. 718-723.

7. Gabathuler R. Approaches to Transport Therapeutic Drugs Across the Blood-Brain Barrier to Treat Brain Diseases. Neurobiology of Disease, 2010, vol. 37, pp. 48-57.

8. Godovskiy Yu.K. Thermophysical Methods of Polymers Study. Moscow, Khimiya Publ., 1976. 216 p. (in Russian).

9. Gonzalez-Montiel A., Keskkula H., Paul D.R. Morphology of Nylon 6/polypropylene Blends Compatibilized with Maleated Polypropylene. J. Pol. Sci. B: Polym. Phys., 1995, vol. 33, p. 1751.

10. Gross R.A., Kalra B. Biodegradable Polymers for the Environment. Science, 2002, vol. 297, no. 5582, pp. 803-807.

11. Hassan C., Peppas N. Biopolymers. PVA Hydrogels. Advances in Polymer Science. Berlin, Springer-Verlag, 2000.

12. Iordanskiy A.L., Olkhov A.A., Kamaev P.P., Wasserman A.M. Water Transport Phenomena in Green and Petrochemical Polymers. Differences and Similarities. Desalination, 1999, vol. 126, pp. 139-145.

13. IordanskiyA.L., Olkhov A.A., Pankova Yu.N., Bonartsev A.P., Bonartseva G.A., Popov V.O.
Hydrophilicity Impact Upon Physical Properties of the Environmentally Friendly Poly(3-hydroxybutyrate) Blends: Modification Via Blending. Macromolecular Symposia. Special Issue: Fillers, Filled Polymers and Polymer Blends, 2006, vol. 233 (no. 1), pp. 108-116.

14. Iordanskiy A.L., Rudakova T.E., Zaikov G.E. Interaction of Polymers With Bioactive and Corrosive Media. Ser. New Concepts in Polymer Science. Utrecht -Tokyo Japan, VSP Science Press, 1994. 298 p.

15. Kamaev P.P., Aliev I.I., Iordanskiy A.L., Wasserman A.M. Molecular Dynamics of the Spin Probes in Dry and Wet Poly(3-hydroxybutyrate) Films With Different Morphology. Polymer, 2001, vol. 42, no. 2, pp. 515-520.

16. Mooney B.P. The Second Green Revolution? Production of Plant-Based Biodegradable Plastics. Biochem. J., 2009, vol. 418, pp. 219-232.

17. Olkhov A.A., Vlasov S.V., Shibryaeva L.S., Kosenko R.Yu., Iordanskiy A.L. Morphology of LDPEPoly(3-hydroxybutyrate) Films. AIP Conf. Proc. (American Institute of Physics), 2012, vol. 1459, pp. 290-292.

18. Olkhov A.A., Vlasov S.V., Shibryaeva L.S., Litvinov I.A., Tarasova N.A., Kosenko R.Yu., Iordanskiy A.L. Structural Features of LDPE-Poly(3hydroxybutyrate) Blends. Polymer Science, Ser. A., 2000, vol. 42 (no. 4), pp. 447-452.

19. Olkhov A.A., Iordanskiy A.L., Zaikov G.E. Morphology and Mechanical Parameters of Biocomposite Based on LDPE-PHB. Journal of the Balkan Tribological Association, 2014, vol. 20 (no. 1), pp. 101-110.

20. Olkhov A.A, Vlasov S.V., Iordanskiy A.L., Zaikov G.E., Lobo V.M. Water Transport, Structure Features and Mechanical Behavior of Biodegradable PHB/PVA Blends. J. Appl. Polymer. Sci., 2003, vol. 90, pp. 1471-1476.

21. Pankova Yu.N., Shchegolikhin A.N., Iordanskiy A.L., Zhulkina A.L., Olkhov A.A., Zaikov G.E. The Characterization of Novel Biodegradable Blends Based on Polyhydroxybutyrate: The Role of Water Transport. Journal of Molecular Liquids, 2010, vol. 156, no. 1, pp. 65-69.

22. Paul D., Newman S., eds. Polymer Blends. New York, Academic, $1979.356 \mathrm{p}$.

23. Rowland S., ed. Water in Polymers. Am. Chem. Soc. Washington, $1980.40 \mathrm{p}$.

24. Rozenberg M. Polymers based on vinyl acetate. Leningrad, Khimiya Publ., 1983. 176 p. (in Russian).

25. Shapochkin V.I., Semenova L.M., Bakhracheva Yu.S., Gyulikhandanov E.L., Semenov S.V. Effect of Nitrogen Content on the Structure and Properties of Nitrocarburized Steel. Metal Science and Heat Treatment, 2011, vol. 52, no. 9-10, pp. 413419. 


\section{ТЕХНИКО-ТЕХНОЛОГИЧЕСКИЕ ИННОВАЦИИ}

26. Siracusa V., Rocculi P., Romani S., Rosa M. Dalla Biodegradable Polymers for Food Packaging: a Review. Trends in Food Science \& Technology, 2008. DOI: 10.1016/j.tifs.2008.07.003.

27. Terada M., Marchessault R.H. Determination of Solubility Parameters for Poly(3-hydroxyalkanoates). International Journal of Biological Macromolecules, 1999, vol. 25, pp. 207-215.

28. Williams C.G., Macpherson J.V., Unwin P.R., Parkinson C. Laser Scanning Confocal Microscopy Coupled With Hydraulic Permeability Measurements for Elucidating Fluid Flow Across Porous Materials:
Application to Human Dentine. Analytical Sciences, 2008, vol. 24 (no. 4), pp. 437-442.

29. Ying Hu, Robert H. Thermodynamics of Carbonaceous Mesophase II. General Theory for Nonideal Solutions. Hurt. Carbon., 2001, 39, pp. 887-896.

30. Zaikov G.E., Pearce E.M., Kirshenbaum G., eds. New Steps in Physical Chemistry, Chemical Physics and Biochemical Physics. New York, Nova Science Publishers, Inc. 2013. 318 p.

31. Zhong Z.W., Song B., Huang C.X. Environmental Impacts of Three Polyhydroxyalkanoate Manufacturing Processes. Materials and Manufacturing Processes, 2009, vol. 24 (no. 5), pp. 519-523.

\section{БИОРАЗЛАГАЕМЫЕ СМЕСИ НА ОСНОВЕ ПОЛИГИДРОКСИБУТИРАТА: СТРУКТУРА И ДИФФУЗИЯ ВОДЫ \\ Ольхов Анатолий Александрович}

Кандидат технических наук, доцент, старший научный сотрудник лаборатории перспективных композиционных материалов и технологий, РЭУ им. Г. В. Плеханова aolkhov72@yandex.ru Стремянный переулок, 36, 117997 г. Москва, Российская Федерация

\section{Маркин Валерий Сергеевич}

Кандидат химических наук,

старший научный сотрудник лаборатории диффузионных явлений в полимерных системах, Институт химической физики им. Н. Н. Семенова РАН aolkhov72@yandex.ru ул. Косыгина, 4, 119991 г. Москва, Российская Федерация

\section{Косенко Регина Юделевна}

Кандидат химических наук,

старший научный сотрудник лаборатории диффузионных явлений в полимерных системах, Институт химической физики им. Н. Н. Семенова РАН aolkhov72@yandex.ru ул. Косыгина, 4, 119991 г. Москва, Российская Федерация

\section{Гольдштрах Марианна Александровна}

Кандидат химических наук,

научный сотрудник лаборатории диффузионных явлений в полимерных системах, Институт химической физики им. Н. Н. Семенова РАН aolkhov72@yandex.ru ул. Косыгина, 4, 119991 г. Москва, Российская Федерация 


\section{Заиков Геннадий Ефремович}

Доктор химических наук, профессор, заведующий отделом биологической и химической физики полимеров, Институт биохимической физики им. Н. М. Эмануэля РАН chembio@sky.chph.ras.ru ул. Косыгина, 4, 119334 г. Москва, Российская Федерация

\section{Иорданский Алексей Леонидович}

Доктор химических наук, профессор, заведующий лабораторией диффузионных явлений в полимерных системах, Институт химической физики им. Н. Н. Семенова РАН aolkhov72@yandex.ru ул. Косыгина, 4, 119991 г. Москва, Российская Федерация

\section{Панкова Юлия Николаевна}

Кандидат химических наук, научный сотрудник лаборатории диффузионных явлений в полимерных системах, Институт химической физики им. Н. Н. Семенова РАН aolkhov72@yandex.ru ул. Косыгина, 4, 119991 г. Москва, Российская Федерация

Аннотация. Настоящая статья посвящена изучению взаимодействия смесей на основе поли(3-гидроксибутирата) (ПГБ) и полимеров с различной гидрофильности. Полимерные смеси были изготовлены из пяти соотношений в целях регулирования на устойчивость к гидролизу или (био)деградации посредством контроля водопроницаемости.

Ключевые слова: биоразлагаемые полимерные смеси, полигидроксибутират, полиамид, поливиниловый спирт, полиэтилен, структура, диффузия воды. 